\section{HSE}

Historia Social y de la Educación

Social and Education History
Hipatia Press

www.hipatiapress.com

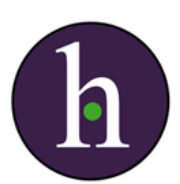

Instructions for authors, subscriptions and further details:

$\underline{\text { http://hse.hipatiapress.com }}$

\title{
List of Reviewers
}

Date of publication: February $23^{\text {rd }}, 2016$

Edition period: Edition period: February 2016-June2016

To cite this article: HSE Editors. (2016). List of Reviewers. Social and Education History, 5(1), 111. doi: 10.17583/hse.\%Y.1970

To link this article: http://dx.doi.org/10.17583/hse.\%Y.1970

\section{PLEASE SCROLL DOWN FOR ARTICLE}

The terms and conditions of use are related to the Open Journal System and to Creative Commons Attribution License (CC-BY). 


\section{List of Reviewers}

The editors of the Social and Education History, we wish thank the reviewers for their contributions to the quality of the journal during 2015.

Carme GarcíaYeste

Sandra Girbés

Editor
Álvarez Fernández, A.
Beltrán Alonso, Haens
Cabré, Joan
Cifuentes, Asunción
De Cabo, Isabel
Delgado, Antonio
Foncillas, Mercedes
Gabassa, Vanessa
Groves, Tamar
Jiménez, Jose Miguel
López Sabatel, Jose Antonio
Marco, Luís
Marcos, Josep
Mondejar, Eduard
Paradís, Ricard
Prieto Jiménez, Esther

2016 Hipatia Press

ISSN: 2014-3567

DOI: 10.17583/hse.\%Y.1970
Pulido, Miquel Angel

Pulido, Cristina

Renta, Ana Inés

Ruiz, Laura

Sánchez Blando, Laura

Valls, Rosa 